\title{
JAK/STAT-deficient cell lines
}

\section{C.A. Bonjardim}

\section{Correspondence}

C.A. Bonjardim

Laboratório de Vírus

Departamento de Microbiologia

ICB, UFM G, Bloco F4-258

Av. Antonio Carlos, 6627

31270-901 Belo Horizonte, MG

Brasil

Fax: + 55-31-498-1510

E-mail: claubonj@mono.icb.ufmg.br

The author was the recipient of a post-doctoral fellowship from CNPq.

Received February 12, 1998 Accepted August 10, 1998
Laboratório de Vírus, Departamento de Microbiologia,

Universidade Federal de M inas Gerais, Belo Horizonte, MG, Brasil

\section{Abstract}

Mutant cell lines B3 and B10, which are unresponsive to both interferon (IFN)- $\alpha$ and IFN- $\gamma$, and line B9, which does not respond to IFN- $\gamma$ stimulation, are described. The mutants were submitted to fluorescence-activated cell sorting (FACS) from a cellular pool, which was obtained from the parental cell line 2C4 after several rounds of mutagenesis. The unresponsiveness to IFN stimulation was observed both in terms of expression of cell surface markers (CD2, class I and II HLAs) and mRNA expression of IFN-stimulated genes (2'-5' oligoadenylate synthetase (OAS), 9-27, and guanylate binding protein (GBP)). Genetic crossing of B3, B9 and B10 with U3 (STAT1 ${ }^{-}$), $\gamma 2 \mathrm{a}$ $\left(\mathrm{JAK} 2^{-}\right)$and $\mathrm{U} 4\left(\mathrm{JAK}^{-}{ }^{-}\right)$mutants, respectively, did not restore IFN responsiveness to the hybrid cell lines. However, when these cell lines were crossed with the same mutants, but using the pairwise crosses B3 $\mathrm{x} \mathrm{U} 4, \mathrm{~B} 9 \mathrm{x} \mathrm{U} 3$ and B10 x U3, the cell hybrids recovered full IFN responsiveness. The present genetic experiments permitted us to assign the mutant cell lines B3, B9 and B10 to the U3, $\gamma 2$ and U4 complementation groups, respectively. These conclusions were supported by the analysis of IFN-stimulated genes in the mutants.

\author{
Key words \\ - Interferons \\ - JAK/STAT \\ - Molecular genetics \\ - FACS analysis \\ - RN ase protection \\ - Transcriptional activation \\ .........................
}

\section{Introduction}

Our knowledge of cytokine signalling has experienced enormous progress in the past few years due to the combined utilization of somatic cell genetics, biochemical analysis and transgenic animals (1-4). The first well established cytokine transduction pathway was determined in studies carried out with mutant cell lines which had previously been characterized as interferon (IFN)unresponsive cells ( $U$ and $\gamma$ mutants), followed by complementation of their defects by cDNA transfection $(5,6)$. Thus, IFNs, whose main biological activities are antiviral, antiproliferative and modulatory effects exerted on the immune system (7), send their signals to the cell nucleus by activating a cascade of signalling molecules via tyrosine phosphorylation (8), which includes a fam- ily of non-receptor protein tyrosine kinases (NRPTK) known as JAKs or Janus kinases, comprising JAK1-3 and TYK2 (9) and latent cytoplasmic proteins termed STATs (signal transducers and activators of transcription), owing to the dual role played by these molecules (10). Type I IFN (mainly $\alpha$ and $\beta$ ) transduces its signals to the nucleus through the NRPTK JAK1 and TYK2, STAT1 and STAT2 in association with $\mathrm{p} 48(11,12)$, while type II IFN $(\gamma)$ utilizes JAK1 and JAK2, in addition to a STAT1 $\alpha$ dimer $(13,14)$. After being translocated to the nucleus these protein complexes recognize and bind to cognate cis-acting DNA elements, i.e., ISRE IFN-sitimulated response element, for type I IFNs $(15,16)$, and GAS - gamma activator sequence, for type IIIFN $(17,18)$, positioned in the regulatory region of the IFN-stimulated genes (ISGs), promoting their transcrip- 
tional activation $(2,9)$. The signal transduced by the JAK/STAT pathway is terminated by the interaction of JAB (JAK-binding protein) with JAK, resulting in a reduced tyrosine kinase activity of the protein (19). Protein tyrosine phosphatases have also been reported to be downregulators of the signal transmission to the nucleus $(20,21)$. The $\mathrm{U}$ mutants mentioned earlier proved to be fundamental in the elucidation of the signal transduction pathway triggered by JAK/ STAT proteins upon cytokine stimulation (22-25). These mutants were characterized based on selection of the growing cells in HAT (hypoxanthine, aminopterin, and thymidine) plus IFN- $\alpha$, although constitutive mutants could be obtained under HAT selection without IFN (22,23; Bonjardim CA, unpublished observations). Here I describe the JAK/STAT-deficient cell lines B3, B9 and $\mathrm{B} 10$, which were cloned by an alternative selection procedure based on the expression of cell surface markers, followed by fluorescence-activated cell sorter (FACS) analysis. These mutant cell lines were further characterized biochemically and were assigned to the $\mathrm{U} 3\left(\mathrm{STAT}^{-}\right)$(23), $\gamma 2$ $\left(\mathrm{JAK}^{-}\right)$(26) and U4 (JAK1 ${ }^{-}$) (23) complementation groups, respectively.

\section{Material and Methods}

\section{Cell culture, cell fusion and DNA transfection}

Cells were cultured in Dulbecco's modified Eagle's medium (DMEM) supplemented with $10 \%(\mathrm{v} / \mathrm{v})$ heat-inactivated fetal calf serum, $5 \mu \mathrm{M}$ L-glutamine, and neomycin $(\mathrm{G} 418,700 \mu \mathrm{g} / \mathrm{ml})$ and incubated at $37^{\circ} \mathrm{C}$ in the presence of $5 \% \mathrm{CO}_{2}$. The parental cell line 2C4 was generated from the human fibrosarcoma cell line HT1080, which was obtained from the American Type Culture Collection (ATCC), Parklawn Drive, Rockville, MD, as described elsewhere (12). Briefly, human HT1080 cells were co-transfected with a selectable marker, pTKNeo, and pDW9-27CD2, a plasmid containing the promoter region of the IFN-stimulated gene 9-27 placed just upstream of a full-length CD2 cDNA. 2C4 cells were mutagenized (five rounds) with the frameshift agent ICR191 (21) and the cell population was subdivided into different pools (a gift from D. Watling, ICRF, London). B3, B9 and B10 were FACS sorted from these pools, cloned and characterized. U3, $\gamma 2 \mathrm{~A}$ and U4 mutants were characterized as described elsewhere $(23,26)$, and are unresponsive to type I and type II IFN (U3 and U4) or unresponsive to type II only $(\gamma 2 \mathrm{~A})$. The mutations were mapped to (STAT1 $\left.\alpha^{-} / 1 \beta^{-}\right)$: U3 (14), (JAK2-): $\gamma 2 \mathrm{~A}$ (26) and (JAK1- ${ }^{-}$): U4 (12).

For cell fusion experiments a puromycin- or hygromycin-dominant selectable marker was transfected into the cells and the resistant hybrid cell population was maintained in the presence of the adequate drug. Cell fusion experiments employing PEG 4000 (Sigma Chemical Co., St. Louis, MO) were performed as described elsewhere (22). Briefly, $1 \times 10^{6}$ cells of each cell line to be fused were pelleted together in a refrigerated centrifuge (500 g, $5 \mathrm{~min}$ ). Cell pellets were resuspended in 50\% PEG 4000 and left at room temperature for $1 \mathrm{~min}$, followed by the addition of $3 \mathrm{ml}$ of DMEM without SFB for $2 \mathrm{~min}$ at the same temperature. Finally, the cell suspension was diluted with an equal volume of medium without SFB. Cells were then centrifuged as above, and the pellet was resuspended in DMEM supplemented with $15 \%$ SFB, split into 2 culture dishes and incubated at $37^{\circ} \mathrm{C}$ in the presence of $5 \% \mathrm{CO}_{2}$ overnight. The medium was then replaced with DMEM + 10\% SFB supplemented with the selectable drug.

\section{FACS analysis}

Fluorescence-activated cell sorter (FACSCAN, Becton Dickinson, New Jersey, USA) analysis was performed as previously described $(13,27)$. Briefly, 5 x $10^{5}$ 
cells were seeded on a 10-cm Petri dish and after overnight incubation they were treated with $10^{3} \mathrm{IU} / \mathrm{ml}$ of a highly purified mixture of IFN- $\alpha$ (Wellferon, $1.5 \times 10^{8}$ IU per mg protein, Wellcome Research Laboratories, Beckenham, Kent, UK), or recombinant human IFN- $\gamma\left(2 \times 10^{7}\right.$ IU per mg protein) a generous gift from Dr. G. Adolf, Ernst Boehringer Institut für Arzneimittelforschung, Vienna, Austria. Cells were treated with IFN for 48-72 $\mathrm{h}$ and then incubated with antibodies as described previously $(13,27)$ for $1 \mathrm{~h}$ at $0^{\circ} \mathrm{C}$. Cells were pelleted, resuspended in PBS, fixed in $1 \%$ paraformaldehyde and analyzed in a FACS using a Consort 30 program (3000 data points).

\section{RNase protection assay}

Cytoplasmic RNA was obtained from monolayer cells by NP40 lysis and phenol/ chloroform extraction. Probes were synthesized from the SP6/T7 transcription vectors pGEMs 3 and 4 (Promega, Madison, WI), labelled with $\left({ }^{32} \mathrm{P}\right) \alpha \mathrm{UTP}$ (Amersham, Beckingham, UK) to a specific activity of $>10^{8} \mathrm{cpm} / \mu \mathrm{g}$ DNA. Ten $\mu \mathrm{g}$ of RNA was resuspended in $80 \%$ formamide, mixed with $1-3 \times 10^{5} \mathrm{cpm}$ of each probe, heated to $85^{\circ} \mathrm{C}$ for $10 \mathrm{~min}$, and then incubated overnight at $47^{\circ} \mathrm{C}$. Single-stranded RNA was digested with ribonucleases A $(400 \mu \mathrm{g} / \mathrm{ml})$ and T1 (2 $\mu \mathrm{g} / \mathrm{ml}$ ) (Sigma), incubated at $37^{\circ} \mathrm{C}$ for 30 min, followed by treatment with proteinase $\mathrm{K}(10 \mathrm{mg} / \mathrm{ml})$ at $37^{\circ} \mathrm{C}$ for $30 \mathrm{~min}$. Samples were phenol extracted and precipitated with ethanol. Protected double-stranded RNA was resuspended in formamide/dye mix, denatured and resolved on a $6 \%$ polyacrylamideurea gel as described elsewhere (14). Details about the construction and length of the protected fragments of the specific RNase protection probes ( 2 '-5' oligoadenylate synthetase (OAS), 9-27, guanylate binding protein (GBP) and $\gamma$-actin) used in this study have been described elsewhere (14). The 2'5' OAS and 9-27 probes were generous gifts from M. Müller and the GBP probe from T. Decker.

\section{Results}

\section{FACS analysis of the mutant cell lines}

FACS analysis of the mutants B3 and B10 indicated that these cell lines did not respond to IFN- $\alpha$ or IFN- $\gamma$ stimulation (Figure 1A, panels 4-6 and 10-12), respectively, and mutant B9 was not responsive to IFN- $\gamma$ treatment (Figure 1A, panels 7-9) when the cell surface markers CD2 and the endogenous class I and class II HLA were investigated (Figure 1A, panels 4-12). The expression of these genes in response to both IFN$\alpha$ and IFN- $\gamma$ in the parental cell line $2 \mathrm{C} 4$ is also shown (Figure 1A, panels 1-3). The mutation affecting each particular cell line seems to be highly stable since their phenotypes remained the same after several passages in culture for more than three months, as confirmed by their unresponsiveness to IFN stimulation, which was demonstrated by Northern blot assays (data not shown). The B9 mutant was further characterized as shown in Figure 1B. Pairwise crosses between B9 $x$ U3 and B9 $x \gamma 2 \mathrm{~A}$ were carried out and then FACS analyzed as described in Material and Methods. Full IFN- $\gamma$ responsiveness was restored to the cell hybrids B9 $x$ U3 (Figure 1B, panels 13-15, compare with Figure 1A, panels 7-9), while no response to IFN- $\gamma$ was achieved when analyzing the cells from the B9 $\mathrm{x} \gamma 2 \mathrm{~A}$ cross (Figure 1B, panels 16-18, compare with Figure 1A, panels 7-9). The B3 mutant was also further characterized. Figure 1C shows the FACS analysis carried out with pairwise crosses between mutants B3 x U3 and B3 x U4. The hybrid cells (B3/U3) did not regain IFN- $\alpha / \gamma$ responsiveness (Figure 1C, panels 19-21), confirming that mutant B3 is a member of the U3 (STAT1 ${ }^{-}$) complementation group. On the other hand, mutant B3 was complemented by fusion with mutant $\mathrm{U} 4\left(\mathrm{JAK} 1^{-}\right)$ 
Figure 1 - FACS analysis of the parental and mutant cell lines. A, 2C4, B3, B9 and B10; B, genetic crosses $B 9 \times U 3$ and $B 9 \times \gamma 2 A$; $C$, pairwise crosses between $B 3$ $x$ U3 and B3 x U4. The expression of the cell surface markers CD2 (panels 2,5,8,11,14,17,20, 23) and endogenous class I (panels $1,4,7,10,13,16,19,22)$ and II HLAs (panels 3,6,9,12,15,18,21, 24) upon IFN- $\alpha$ or IFN- $\gamma$ stimulation $(500 \mathrm{IU} / \mathrm{ml}$ for $48 \mathrm{~h}$ ) was monitored by FACS analysis as described in Material and Methods. Panels 1-3: Parental cell line 2C4; panels 4-6: mutant B3; panels 7-9: mutant B9; panels 1012: mutant B10; panels 13-15: genetic cross between $\mathrm{B} 9$ and the U3 mutant; panels 16-18: genetic cross between $B 9$ and the $\gamma 2 \mathrm{~A}$ mutant; panels 19-21: pairwise crosses between mutants B3 and U3; panels 22-24: pairwise crosses between mutants B3 and U4. Untreated cells (U), IFN- $\alpha(\alpha)$ - or IFN- $\gamma(\gamma)$-treated cells, and unstained cells (US) as indicated. US cells were left untreated or treated with IFN- $\alpha$, but were not incubated with any antibody.

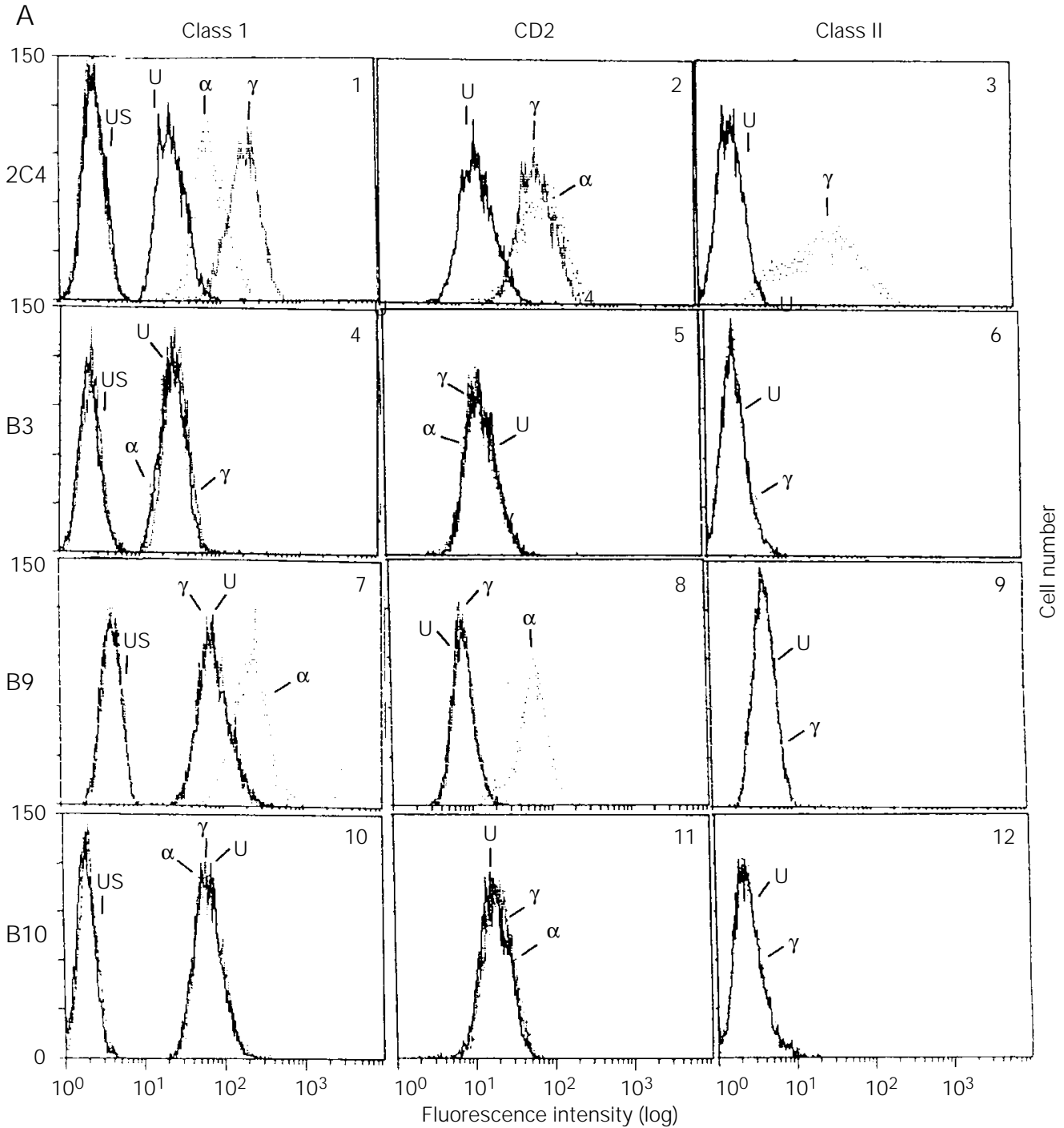

B

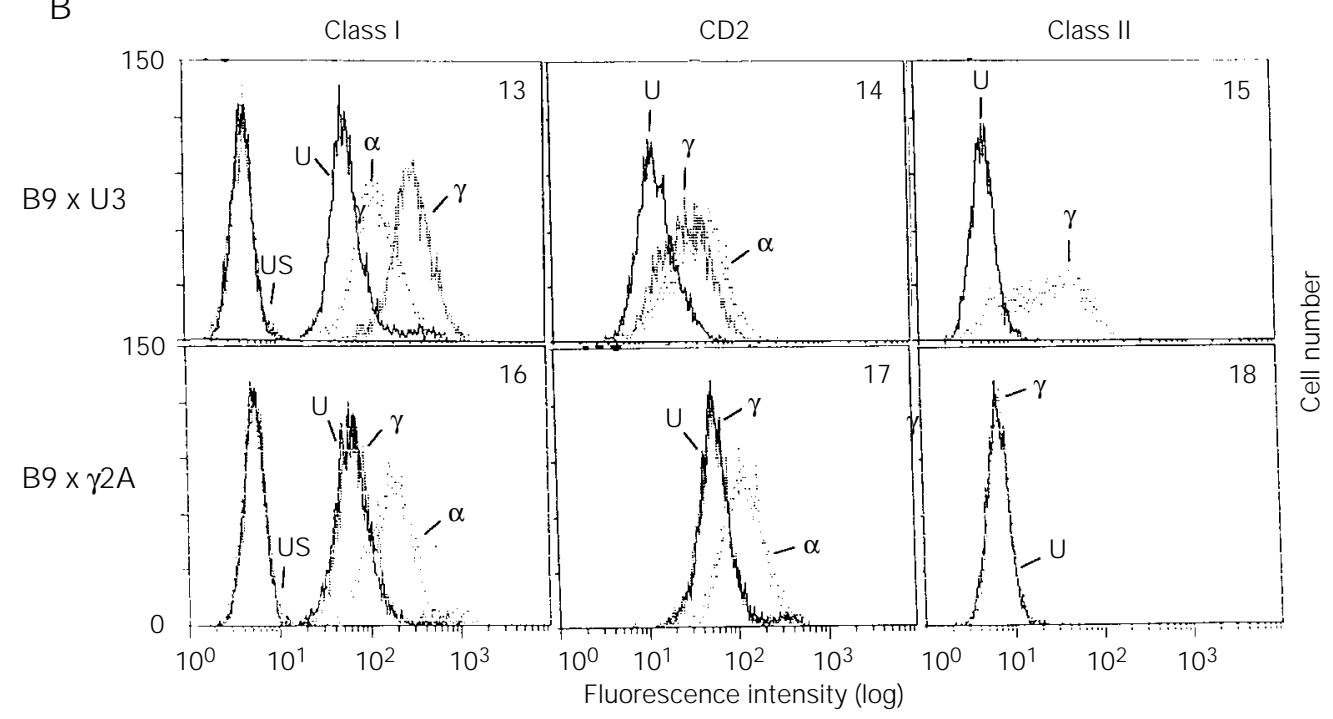




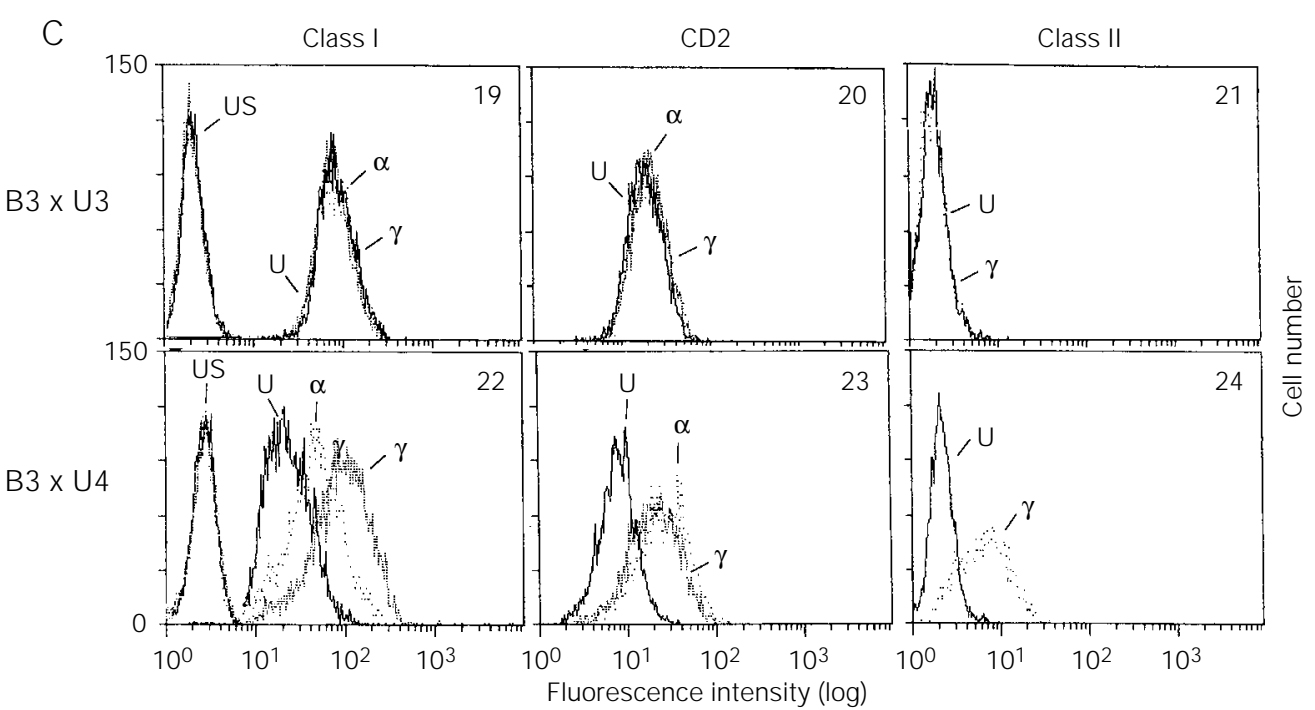

as shown in Figure 1C (panels 22-24), where full IFN responsiveness to the hybrid cells (B3/U4) was observed. The same procedure was also performed to characterize the B10 cell line, except that the pairwise crosses were carried out between $\mathrm{B} 10 \times \mathrm{X} 3$ and B10 $\mathrm{x}$ U4. The B10 mutant was complemented by fusion with mutant $\mathrm{U} 3$, but not with mutant U4, assigning this cell line to the U4 complementation group (data not shown). Figure 1C illustrates the results obtained with the pairwise crosses involving the B10 mutant, since mutants B3 and B10 share the same phenotype (Figure 1A, panels 4-6 and 10-12).

\section{IFN-inducible gene expression}

The mutant phenotypes were also investigated in terms of IFN-stimulated genes. The cells were treated with IFN as indicated, and the protected mRNAs of 2'-5' OAS, 9-27 and GBP were analyzed as shown in Figure 2. The data represent experiments carried out with the B9 mutant. The same procedure was also employed with B3 and B10 cell lines and confirmed the genetic analysis, i.e., they presented total resistance to IFN stimulation (data not shown). The B9 mutant was completely unresponsive to IFN- $\gamma$ stimula- tion, while it retained a full response to IFN$\alpha$. A genetic cross with the U3 mutant restored full IFN- $\gamma$ responsiveness to the hybrid cells (B9 x U3) (compare Figure 2, lanes 6 and 9). These data are in accordance with those obtained by FACS and genetic analysis (Figure 1A, panels 7-9 compared with Figure 1B, panels 13-15).

\section{Discussion}

Impressive progress has been made towards the understanding of the nuclear sig-

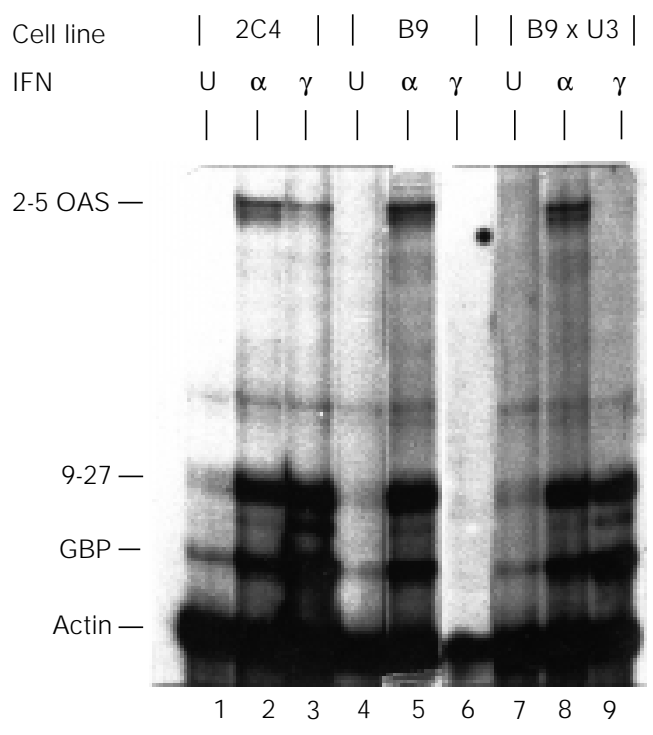

Figure 2 - IFN-stimulated gene expression in the parental cell line $2 \mathrm{C} 4$, in the $\mathrm{B} 9$ mutant and in the hybrid cells $\mathrm{B} 9 \times \mathrm{U} 3$. The expression of 2'-5' OAS, 9-27, and GBP mRNAs in the parental cell line 2C4 (lanes 1-3), in the B9 mutant (lanes 3-6) and in the hybrid cells B9 x U3 (lanes 7-9) was investigated. Cells were left untreated (lanes $1,4,7$ ) or treated with IFN- $\alpha$ (lanes $2,5,8$ ) or IFN- $\gamma$ (lanes 3,6,9), respectively. Cells were incubated with $500 \mathrm{IU} / \mathrm{ml}$ of either IFN- $\alpha$ or IFN$\gamma$ for $6 \mathrm{~h}$ and $18 \mathrm{~h}$, respectively. Cytoplasmic RNA was isolated (10 $\mu \mathrm{g}$ per lane), hybridized with the specific probe as indicated on the left, and analyzed by the RNase protection assay as described in Material and Methods. $\gamma$-Actin was used as an internal standard for RNA loading. 
nals triggered by cytokines, especially IFNs, upon ligand-receptor binding, owing to the converging approaches resulting from the utilization of somatic cell genetics, biochemical analysis and target gene disruption (2830). Thus, the JAK/STAT signalling pathway was first associated to the IFNs and then extended to the other cytokines, as the molecules that elicit the signals from the cell surface to the nucleus upon IFN-receptor binding, and that promote IFN-gene stimulation, which in turn results in the diverse biological activities exerted by these cytokines (31-33). This signal transduction pathway may be further associated not only with cytokines, but also with growth factors and some hormones $(1,34,35)$. In the present study I describe the JAK/STAT-deficient cell lines B3, B9 and B10, which were cloned by using an alternative protocol to the conventional HAT selection (22), based on the expression of cell surface markers upon IFN treatment, followed by FACS analysis. This method has the advantage of not producing constitutive mutants as observed under HAT pressure. The lack of responsiveness to both IFN- $\alpha$ and IFN- $\gamma$ observed in mutants B3 (Figure 1A and C) and B10 (Figure 1A) was associated with defects in the signalling molecules STAT1 and JAK1, respectively, since the response to IFN stimulation was not restored to the hybrid cells (B3 x U3) and
(B10 x U4), while full IFN responsiveness was verified when $\mathrm{B} 3$ and $\mathrm{B} 10$ were crossed with $\mathrm{U} 4$ and $\mathrm{U} 3$, respectively. Thus, mutants $\mathrm{B} 3$ and B10 were assigned to the $\mathrm{U} 3$ and $\mathrm{U} 4$ complementation groups, respectively. The genetic data were further extended to the analysis of ISGs (2'-5' OAS, 9-27, and GBP) which confirmed their phenotypes. Based on these criteria, the mutant cell line B9 was characterized as a member of the $\gamma 2$ complementation group (Figures 1A,B and 2), i.e., it was completely resistant to IFN- $\gamma$ but responded normally to IFN- $\alpha$. Thus, these JAK/ STAT-deficient cell lines may be useful as an alternative to the $\mathrm{U}$ and $\gamma 2 \mathrm{~A}$ mutants, to further elucidate how cytokines and/or growth factors trigger nuclear signalling, and to determine the role of this transduction pathway in regulating the multiplication of intracellular pathogens.

\section{Acknowledgments}

I would like to thank Dr. I.M. Kerr, Imperial Cancer Research Fund, London, for the opportunity to carry out this work in his laboratory. I also thank T. Decker (Vienna Biocenter, Austria) and M. Müller (Imperial Cancer Research Fund, London) for kindly providing the protection probes, and D. Watling (Imperial Cancer Research Fund, London) for the mutagenized cell pool.

\section{References}

1. Leaman DW, Leung S, Li X \& Stark GR (1996). Regulation of STAT-dependent pathways by growth factors and cytokines. FASEB J ournal, 10: 1578-1588.

2. Schindler C \& Darnell J r J E (1995). Transcriptional responses to polypeptide ligands: the JAK-STAT pathway. Annual Review of Biochemistry, 64: 621-651.

3. Matsuyama $T$, Kimura $T$, Kitagawa $M$, Pfeffer K, Kawakami T, Watanabe N, Kündig TM, Amakawa R, Kishihara K, Wakeham A, Potter J, Furlonger CL, Narendran A, Suzuki H, Ohashi PS, Palge C, Taniguchi T \& Mak TW (1993). Targeted disruption of IRF-1 or IRF-2 results in abnormal type I IFN gene induction and aberrant lymphocyte development. Cell, 75: 83-97.

4. Kumar A, Yang YL, Flati V, Der S, Kadereit S, Deb A, Haque J, Reis L, Weissmann C \& Williams BR (1997). Deficient cytokine signaling in mouse embryo fibroblasts with a targeted deletion in the PKR gene: role of IRF-1 and NF-kappaB. EMBO J ournal, 16: 406-416.

5. Ihle J N \& Kerr IM (1995). J AKs and STATs in signaling by the cytokine receptor superfamily. Trends in Genetics, 11: 69-74.

6. Ihle J N (1995). Cytokine receptor signalling. Nature, 377: 591-594.
7. Pestka S, Langer J A, Zoon KC \& Samuel C (1987). Interferons and their actions. Annual Review of Biochemistry, 56: 727777.

8. Karin M \& Hunter T (1995). Transcriptional control by protein phosphorylation: signal transmission from the cell surface to the nucleus. Current Biology, 5: 747-757.

9. Pellegrini $S \&$ Dusanter-Fourt I (1997). The structure, regulation and function of the $J$ anus kinases ( $\mathrm{AKS}$ ) and the signal transducers and activators of transcription (STATs). European J ournal of Biochemistry, 248: 615-633.

10. Darnell J r J E (1997). STATs and gene 
regulation. Science, 277: 1630-1635.

11. Velazquez L, Fellous M, Stark GR \& Pellegrini S (1992). A protein tyrosine kinase in the interferon $\alpha / \beta$ signaling pathway. Cell, 70: 313-322.

12. Müller M, Briscoe J, Laxton C, Guschin D, Ziemiecki A, Silvennoinen O, Harpur AG, Barbieri G, Witthuhn BA, Schindler C, Pellegrini S, Wilks AF, Ihle J N, Stark GR \& Kerr IM (1993). The protein tyrosine kinase J AK1 complements defects in interferon- $\alpha / \mathrm{B}$ and $\gamma$ signal transduction. Nature, 366: 129-135.

13. Watling $D$, Guschin $D$, Müller $M$, Silvennoinen O, Witthuhn BA, Quelle FW, Rodgers NC, Schindler C, Stark GR, Ihle J N \& Kerr IM (1993). Complementation by the protein tyrosine kinase J AK2 of a mutant cell line defective in the interferon gamma signal transduction pathway. Nature, 366: 166-170.

14. Müller M, Laxton $C$, Briscoe J , Schindler C, Improta T, Darnell J r J E, Stark GR \& Kerr IM (1993). Complementation of a mutant cell line: central role of the $91 \mathrm{kDa}$ polypeptide of ISGF3 in the interferonalpha and gamma signal transduction pathways. EMBO J ournal, 12: 4221-4228.

15. Levy DE, Kessler DS, Pine R \& Darnell J $r$ J E (1988). Interferon-induced nuclear factors that bind a shared promoter element correlate with positive and negative transcription control. Genes and Development, 2: 383-393.

16. Dale TC, Rosen J M, Guille MJ , Lewin AR, Porter AC, Kerr IM \& Stark GR (1989). Overlapping sites for constitutive and induced DNA binding factors involved in interferon-stimulated transcription. EMBO J ournal, 8: 831-839.

17. Decker T, Lew DJ \& Darnell J rJ E (1991). Two distinct alpha-interferon-dependent signal transduction pathways may contribute to activation of transcription of the guanylate-binding protein gene. Molecular and Cellular Biology, 11: 5147-5153.

18. Lew DJ , Decker T, Strehlow I \& Darnell J r JE (1991). Overlapping elements in the guanylate-binding protein gene promoter mediate transcriptional induction by alpha and gamma interferons. Molecular and Cellular Biology, 11: 182-191.

19. Endo TA, Masuhara $M$, Yokouchi $M$, Suzuki R, Sakamoto H, Mitsui K, Matsumoto A, Tanimura S, Ohtsubo M,
Misawa H, Miyazaki T, Leonor $\mathrm{N}$, Taniguchi T, Fujita T, Kanakura Y, Komiya $S \&$ Yoshimura A (1997). A new protein containing an $\mathrm{SH} 2$ domain that inhibits J AK kinases. Nature, 387: 921-924.

20. David M, Chen HE, Goelz S, Larner AC \& Neel BG (1995). Differential regulation of the alpha/beta interferon-stimulated J ak/ Stat pathway by the $\mathrm{SH} 2$ domain-containing tyrosine phosphatase SHPTP1. Molecular and Cellular Biology, 15: 70507058.

21. Haque SJ , Wu Q, Kammer W, Friedrich K, Smith J M, Kerr IM, Stark GR \& Williams BR (1997). Receptor-associated constitutive protein tyrosine phosphatase activity controls the kinase function of J AK1. Proceedings of the National Academy of Sciences, USA, 94: 8563-8568.

22. Pellegrini S, J ohn J , Shearer M, Kerr IM \& Stark GR (1989). Use of a selectable marker regulated by alpha interferon to obtain mutations in the signaling pathway. Molecular and Cellular Biology, 9: 4605-4612.

23. McKendry R, J ohn J, Flavell D, Müller M, Kerr IM \& Stark GR (1991). High-frequency mutagenesis of human cells and characterization of a mutant unresponsive to both $\alpha$ and $\gamma$ interferons. Proceedings of the National Academy of Sciences, USA, 88: 11455-11459.

24. Leung S, Qureshi SA, Kerr IM, Darnell J r J E \& Stark GR (1995). Role of STAT2 in the alpha interferon signaling pathway. Molecular and Cellular Biology, 15: 13121317.

25. Lutfalla G, Holland SJ, Cinato E, Monneron D, Reboul J , Rogers NC, Smith J M, Stark GR, Gardiner K, Mogensen KE, Kerr IM \& Uzé G (1995). Mutant U5A cells are complemented by an interferon-alpha beta receptor subunit generated by alternative processing of a new member of a cytokine receptor gene cluster. EMBO J ournal, 14: 5100-5108.

26. Kohlhuber F, Rogers NC, Watling D, Feng J, Guschin D, Briscoe J, Witthuhn BA, Kotenko SV, Pestka S, Stark GR, Ihle J N \& Kerr IM (1997). A J AK1/J AK2 chimera can sustain alpha and gamma interferon responses. Molecular and Cellular Biology, 17: 695-706.

27. Bonjardim CA (1997). A mutant cell line partially responsive to both IFN- $\alpha$ and IFN- $\gamma$. Brazilian J ournal of Medical and Biological Research, 30: 41-50.

28. Darnell J r J E, Kerr IM \& Stark GR (1994). J ak-STAT pathways and transcriptional activation in response to IFNs and other extracellular signaling proteins. Science, 264: 1415-1421.

29. Bhattacharya S, Eckner R, Grossman $S$, Oldread E, Arany Z, D'Andrea A \& Livingston DM (1996). Cooperation of Stat2 and p300/CBP in signalling induced by interferon-alpha. Nature, 383: 344-347.

30. Meraz MA, White J M, Sheehan KC, Bach EA, Rodig SJ , Dighe AS, Kaplan DH, Riley J K, Greenlund AC, Campbell D, CarverMoore K, DuBois RN, Clark R, Aguet M \& Schreiber RD (1996). Targeted disruption of the Statl gene in mice reveals unexpected physiologic specificity in the J AKSTAT signaling pathway. Cell, 84: 431442.

31. Horvath CM \& Darnell J r JE (1996). The antiviral state induced by alpha interferon and gamma interferon requires transcriptionally active STAT1 protein. J ournal of Virology, 70: 647-650.

32. Bromberg J F, Horvath CM, Wen Z, Schreiber RD \& Darnell J rJ E (1996). Transcriptionally active Statl is required for the antiproliferative effects of both interferon alpha and interferon gamma. Proceedings of the National Academy of Sciences, USA, 93: 7673-7678.

33. Briscoe J, Rogers NC, Witthuhn B, Watling $D$, Harpur AG, Wilks AF, Stark GR, Ihle J N \& Kerr IM (1996). Kinasenegative mutants of J AK1 can sustain interferon- $\gamma$-inducible gene expression but not an antiviral state. EMBO J ournal, 15: 799-809.

34. Winston LA \& Hunter T (1995). J ak2, Ras, and Raf are required for activation of extracellular signal-regulated kinase/mitogen-activated protein kinase by growth hormone. J ournal of Biological Chemistry, 270: 30837-30840.

35. Leaman DW, Pisharody S, Flickinger TW, Commane MA, Schlessinger J, Kerr IM, Levy DE \& Stark GR (1996). Roles of J AKs in activation of STATs and stimulation of c-fos gene expression by epidermal growth factor. Molecular and Cellular Biology, 16: 369-375. 


\section{Announcement}

\section{Award in honor of Fred L. Soper (1893-1976) for publications in the field of Inter-American Health}

This is an announcement and call for submission of nominations for the 1999 award in honor of Fred L. Soper, former Director of the Pan American Health Organization (the World Health Organization Regional Office for the Americas) from 1947 to 1958.

In addition to his service with $\mathrm{PAHO} /$ WHO, Dr. Soper played a major role in the fight against yellow fever and other infectious diseases in Brazil as part of his work with the Rockefeller Foundation in the 1920s and 1930s and in the control of typhus in North Africa and Italy during the Second World War. He was one of the truly major figures of the century in inter-American health.

The Award is presented annually to the author or authors of an original scientific contribution comprising new information on, or new insights into, the broad field of public health, with special relevance to Latin America or the Caribbean or both. This may consist of a report, an analysis of new data, experimental or observational, or a new approach to analyzing available data. Preference is given to studies involving more than one discipline and to papers related to infectious disease, a life-long concern of Dr. Soper.

Only papers already published in scientific journals listed in the Index Medicus or in the official journals of the Pan American Health Organization are eligible for consid- eration. Furthermore, the Award is limited to contributions by authors whose principal affiliation is with teaching, research or service institutions located in the countries of Latin America and the Caribbean (including the Centers of the Pan American Health Organization).

The Award Fund is administered by the Pan American Health and Education Foundation (PAHEF), which receives voluntary contributions designated for the purpose and holds them in a separate fund. The Award consists of a suitable certificate and a monetary prize of US $\$ 1000.00$. The winner(s) of the Award each year is nominated by an Award Committee, composed of representatives designated by PAHO and by PAHEF; final selection is made by the Board of Trustees of PAHEF.

Papers submitted by or on behalf of their authors may be considered for the Fred L. Soper Award. For purposes of the 1999 Award, only papers published during calendar year 1998 will be considered; all submissions must be received by 31 March 1999 at the following address:

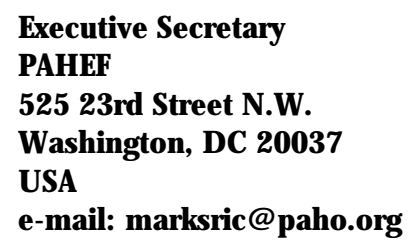

